\title{
Growth and physiological characteristics of the weed false johnsongrass (Sorghum arundinaceum (Desv.) Stapf)
}

\author{
Deborah Amorim Martins', Adriano Jakelaitis ${ }^{3}$, Isabella Sichierski Cardoso ${ }^{4}$, \\ Alan Carlos Costa ${ }^{5}$, Juliana de Fátima Sales ${ }^{6}$
}

10.1590/0034-737X201663010003

\begin{abstract}
Sorghum arundinaceum (Desv.) Stapf a weed that belongs to the Poaceae family and is widespread throughout Brazil. Despite the frequent occurrence, infesting cultivated areas, there is little research concerning the biology and physiology of this species. The objective of this research was to evaluate the growth, carbon partitioning and physiological characteristics of the weed Sorghum arundinaceum in greenhouse. Plants were collected at regular intervals of seven days, from 22 to 113 days after transplanting (DAT). In each sample, we determined plant height, root volume, leaf area and dry matter, and subsequently we performed the growth analysis. We have determined the dry matter partitioning among organs, the accumulation of dry matter, the specific leaf area, the relative growth rate and leaf weight ratio. At 36, 78 and 113 DAT, the photosynthetic and transpiration rates, stomatal conductance, $\mathrm{CO}_{2}$ concentration and chlorophyll fluorescence were evaluated. The Sorghum arundinaceum reached $1.91 \mathrm{~m}$ in height, with slow initial growth and allocated much of the biomass in the roots. The photosynthetic rate and the maximum quantum yield of FSII are similar throughout the growth cycle. At maturity the Sorghum arundinaceum presents higher values of transpiration rate, stomatal conductance and non-photochemical quenching coefficient (NPQ).
\end{abstract}

Key words: growth analysis, gas exchange, chlorophyll a fluorescence.

\section{RESUMO}

\section{Crescimento e características fisiológicas da planta daninha falso-massambará (Sorghum arundinaceum (Desv.) Stapf)}

Sorghum arundinaceum (Desv.) Stapf é uma planta daninha pertencente à família Poaceae e encontra-se disseminada em todo o território brasileiro. Apesar da ocorrência frequente, infestando áreas cultivadas, são poucas as pesquisas concernentes à biologia e à fisiologia desta espécie. Objetivou-se com esta pesquisa avaliar o crescimento, a partição de fotoassimilados e as características fisiológicas da planta daninha Sorghum arundinaceum, em casa de vegetação. As plantas foram coletadas em intervalos regulares de sete dias, a partir de 22 e até 113 dias após o transplantio (DAT). Em cada coleta, determinaram-se altura de plantas, volume de raiz, área foliar e massa seca e, posteriormente, aplicou-se a análise de crescimento, sendo calculada a partição de massa seca entre os órgãos, o acúmulo de massa seca, a área foliar específica, a taxa de crescimento relativo e a razão de peso foliar. Aos 36, 78 e 113 DAT foram avaliadas as taxas fotossintética e transpiratória, a condutância estomática, a relação entre a concentração

\footnotetext{
Submitted on 03/27/2014 and approved on 10/20/2015.

Extraído da dissertação de mestrado da primeira autora.

2 Instituto Federal Goiano, Rio Verde, Goiás, Brasil. deborahamartins@gmail.com

${ }^{3}$ Instituto Federal Goiano, Rio Verde, Goiás, Brasil. ajakelaitis@yahoo.com.br

${ }^{4}$ Instituto Federal, Rio Verde, Goiás, Brasil. isabellacardoso-rv@ hotmail.com

${ }^{5}$ Instituto Federal Goiano, Rio Verde, Goiás, Brasil.alcarcos@gmail.com

' Instituto Federal, Rio Verde, Goiás, Brasil. julianacefetrv@yahoo.com.br

Corresponding author: deborahamartins@gmail.com
} 
interna e externa de $\mathrm{CO}_{2}$ e a fluorescência da clorofila a. O Sorghum arundinaceum apresentou a altura de 1,91 metros, com crescimento inicial lento e alocou grande parte da biomassa nas raízes. A taxa fotossintética e o rendimento quântico máximo do FS II são semelhantes, durante todo o ciclo de crescimento. Na maturação, o Sorghum arundinaceum apresenta maiores valores de taxa transpiratória, condutância estomática e coeficiente de dissipação não fotoquímico (NPQ).

Palavras-chaves: análise de crescimento, trocas gasosas, fluorescência da clorofila a.

\section{INTRODUCTION}

Weeds interfere with the productivity of agricultural crops, mainly because of competition for water, light and nutrients. For its rusticity, weeds stand out for the speed and utilization efficiency of environmental resources (Myers \& Anderson, 2003), ensuring their survival and growth advantages, surpassing cultivated plants. The Poaceae family presents significant number of species that have become invasive in Brazil, especially fodder of African origin, specially Hyparrhenia rufa (Ness) Stapf (H. rufa), Urochloa spp. (brachiaria) and Panicum maximum Jacq. (guineagrass). According to Castro at al. (2011), the fodder grasses have caused significant damage to major crops in Brazil.

Sorghum arundinaceum (Desv.) Stapf is a weed from the Poaceae family, originally from Africa, that has been widespread in all regions of Brazil, and is an annual or perennial plant, erect, with $1.5-2.5 \mathrm{~m}$ tall. Its propagation occurs through seeds, infesting especially annual and perennial crops, vacant lands and roadsides. It is confused with Sorghum halepense, L. Peers which is distinguished for being perennial, rhizomatous and smaller (Lorenzi, 2008).

The growth analysis of poaceae weeds of tropical regions has received little research attention, and the estimates of parameters such as leaf area, specific leaf area, leaf weight ratio and growth rates are scarce. These analyzes are the most accurate and affordable method to evaluate the growth and to measure the contribution of different physiological processes for plant behavior (Benincasa, 2003). By photosynthesis, plants absorb the active solar radiation and incorporate atmospheric $\mathrm{CO}_{2}$ into carbon compounds intended for plant growth. Thus, factors such as the reduction of solar radiation on the leaves decrease the amount of radiation absorbed by the photosynthetic apparatus, which reduces the conversion of light energy into chemical energy, affecting the growth and development of the plants (Aumonde $a t$ al., 2013).

For these reasons, the studies related to the growth and development of weeds allow necessary information on the phenology and growth patterns, providing subsi- dies for the understanding of its physiological and morphological responses, in face of environmental factors and their effect on the ecological niche, especially their interference on cultivated plants.

The aim of this study was to evaluate growth, photoassimilate partitioning and the physiological characteristics of the weed Sorghum arundinaceum in greenhouse, considering the importance of these studies to the knowledge of the ecology of this species.

\section{MATERIAL AND METHODS}

The experiment was conducted in an acclimatized greenhouse, with temperature varying from 18 to $29^{\circ} \mathrm{C}$, on the premises of the Ecophysiology Laboratory and Plant Productivity, of the Instituto Federal Goiano, Campus Rio Verde, from August to December 2012. The location of the experiment has the following geographical coordinates: latitude $17^{\circ} 48^{\prime}$ and $67^{\prime \prime} \mathrm{S}$ and longitude $50^{\circ} 54^{\prime} 18^{\prime \prime} \mathrm{W}$, on average altitude of 758 meters.

The seeds of $S$. arundinaceum were collected in soybean crops of Rio Verde and germinated in plastic boxes $(11 \times 11 \times 3 \mathrm{~cm})$, Gerbox type, sown on two sheets of blotting paper, moistened with distilled water, in an amount equivalent to 2.5 times the weight of the dry substrate in accordance with the Rules for Seed Testing (Brasil, 2009). The boxes were kept in a germinator, with temperature alternating from $19-30^{\circ} \mathrm{C}$ and photoperiod of eight hours of fluorescent white light during the highest temperature. After germination, when there was protrusion of the primary roots three plants were transplanted, to each experimental unit.

The experimental units consisted in eight-liter pots fulfilled with a mixture of sand: subsoil in a 1:2 proportion. The subsoil physico-chemical characteristics were as follow: $\mathrm{pH}=5.5 ; \mathrm{P}=0.35 \mathrm{mg} \mathrm{dm}^{-3} ; \mathrm{K}=19.6 \mathrm{mg} \mathrm{dm}^{-3} ; \mathrm{Ca}=$ $1.4 \mathrm{cmol}_{\mathrm{c}} \mathrm{dm}^{-3} ; \mathrm{Mg}=0.26 \mathrm{cmol}_{\mathrm{c}} \mathrm{dm}^{-3} ; \mathrm{Al}=0.03 \mathrm{cmol}_{\mathrm{c}} \mathrm{dm}^{-3}$; $\mathrm{V} \%=53.2 \% ; \mathrm{CEC}=3.31 \mathrm{cmol}_{\mathrm{c}} \mathrm{dm}^{-3}$ and granulometry 23 , 5 , and $72 \mathrm{~kg} \mathrm{dag}^{-1}$ clay, silt and sand, respectively. Afterwards, $184 \mathrm{~g}$ of N, $836 \mathrm{~g}$ of $\mathrm{P}_{2} \mathrm{O}_{5}, 110 \mathrm{~g}$ of $\mathrm{K}_{2} \mathrm{O}$ and 64 $\mathrm{g}$ of Ca plus $\mathrm{Mg}$ were added to the soil at a ratio of two portions of soil to one portion of sand. The pots were watered daily and manually, maintaining the substrate at 
field capacity. Fertilization was made with nutrient solution of Hoagland \& Arnon (1950) every two weeks.

The experiment was installed in an experimental design of randomized blocks, with 14 treatments (harvest periods) and four replications. The periods corresponded to 22, $29,36,43,50,57,64,71,78,85,92,99,106$ and 113 days after transplantation (DAT). In each evaluation period, the plants were separated into roots, stems, leaves, panicles and seeds. Root volume was measured using a graduated cylinder; the height of the plants, with a millimeter ruler, measuring the length of the stem to the apex of the plant; and the leaf area through the Sigma Scan software Prov. 5.0, Jandel Scientific. Subsequently, the sampled material was packed in paper bags and dried in an oven with forced ventilation at $70^{\circ} \mathrm{C}$ for 72 hours until reaching constant mass.

The dry matter of root (RDM), stems (SDM), leaves (LDM), seeds (SDM) and panicles (PDM) were measured (in g per plant) in a digital analytical scale, also being obtained total dry matter (TDM). The specific leaf area (SLA), leaf weight ratio (LWR) and relative growth rate (RGR) were calculated based on leaf area and dry matter of the different plant parts, in the resoective sampling periods, according to Benicasa (2003) and Aguilera at al. (2004). Data were statistically analyzed using the $\mathrm{F}$ test on the analysis of variance, followed by the application of non-linear regression models, in function of the harvest periods.

The physiological evaluations of gas exchange and chlorophyll $a$ fluorescence were performed in three phenological phases: the vegetative growth (36 DAT), the flowering period (78 DAT) and maturation (113 DAT). The gas exchanges related to the photosynthetic rate $\left(A\right.$, ì mol m $\left.\mathrm{m}^{-2} \mathrm{~s}^{-1}\right)$, transpiration rate $\left(E, \mathrm{mmol} \mathrm{m} \mathrm{m}^{-2} \mathrm{~s}^{-1}\right)$, stomatal conductance $\left(g_{\mathrm{s}}, \mathrm{mol} \mathrm{H}_{2} \mathrm{O} \mathrm{m}^{-2} \mathrm{~s}^{-1}\right)$ and the ratio between the internal and external concentrations of $\mathrm{CO}_{2}$ $(\mathrm{Ci} / \mathrm{Ca})$ were determined by an infrared gas analyzer Model LI-6400XTR (Licor®, Nebraska, USA). Measurements were performed between $8 \mathrm{~h} 30 \mathrm{~min}$ and $10 \mathrm{~h} 30 \mathrm{~min}$ in a greenhouse, using constant $(1000 \mu \mathrm{mol}$ photons $\left.\mathrm{m}^{-2} \mathrm{~s}^{-1}\right)$ photosynthetically active radiation (PAR), atmospheric concentration of $\mathrm{CO}_{2}(\mathrm{Ca})(\sim 400 \mu \mathrm{mol}$ $\left.\mathrm{mol}^{-1}\right)$, leaf chamber temperature $\left(25-35^{\circ} \mathrm{C}\right)$ and leaf temperature $\left(30-35^{\circ} \mathrm{C}\right)$.

Fluorescence measurements of chlorophyll $a$ were evaluated using a portable modulated fluorometer, model MINI-PAM (Walz, Effeltrich, Germany), equipped with a special gripper for leaf support, model 2030-B (Rascher at al., 2000). Initially, the leaves were adapted to dark for 30 minutes and, after this period, leaf tissues were exposed to a modulated red light $\left(0.03-\mu \mathrm{mol} \mathrm{m} \mathrm{m}^{-2} \mathrm{~s}^{-1}\right)$ and the initial fluorescence $\left(\mathrm{F}_{0}\right)$ was determined. Then, a pulse of $0.8 \mathrm{~s}$ of saturating actinic light $\left(>6000 \mu \mathrm{mol} \mathrm{m} \mathrm{m}^{-2} \mathrm{~s}^{-1}\right)$ was applied and the maximal fluorescence (Fm) was determined. With these results, the potential quantum yield of the photosystem II was estimated, using the equation Fv/Fm $=\left(\mathrm{Fm}-\mathrm{F}_{0}\right) / \mathrm{Fm}$.

The effective quantum yield of photosystem II was determined by superimposing a saturation pulse on leaves previously adapted to environmental light, and calculated as $\Delta \mathrm{F} / \mathrm{Fm}^{1}=\left(\mathrm{Fm}^{1}-\mathrm{F}\right) / \mathrm{Fm}^{1}$, where $\mathrm{F}$ is the maximum fluorescence yield during the saturation pulse (Genty at al., 1989). The $\Delta \mathrm{F} / \mathrm{Fm}^{1}$ was used to estimate the apparent electron transport rate (ETR) by using the equation $\mathrm{ETR}=\Delta \mathrm{F} / \mathrm{Fm}^{1} \times \mathrm{PFD} \times 0.5 \times 0.84$, where $\mathrm{PFD}$ is the photon flux density $\left(\mu \mathrm{mol} \mathrm{m} \mathrm{m}^{-2} \mathrm{~s}^{-1}\right)$ incident on the leaf; 0.5 is the value corresponding to the fraction of excitation energy distributed to the FSII and 0.84 is the value corresponding to the fraction of incident light absorbed by the leaves.

The non-photochemical quenching coefficient of Stern-Volmer was calculated as NPQ $=($ Fm-Fm' $) / F m$ ' (Bilger \& Björkman, 1990). As described for gas exchange, the evaluations with portable fluorometer were performed between $08 \mathrm{~h} 30 \mathrm{~min}$ and $10 \mathrm{~h} 30 \mathrm{~min}$, always in the same area of each leaf being evaluated.

The data relating to the physiological variables were submitted to descriptive analysis, followed by the standard error of the mean.

\section{RESULTS AND DISCUSSION}

The data obtained for plant height and root volume height and root volume (Figure 1A and B) and those of dry matter accumulation in plant parts (Figures 2A, B, C, D) over the cycle of $S$. arundinaceum, were adjusted to a logistic model of the type $Y=a /[1+\exp -(x-b / c)]$, where $\mathrm{Y}$ is the dependent variable in question and $\mathrm{X}$ is the independent variable (time), and $a, b$ and $c$ are the estimated parameters of the equation.

In the model estimated for the height of $S$. arundinaceum, it is observed that the weed stands out for its size, reaching 1.91 meters at 113 DAT (Figure 1A). The height of plants is an important feature and can influence the competition relations between plants, depending on the neighboring species, their growth behaviors and coexistence period (Zanine \& Santos, 2004). The coexistence of $S$. arundinaceum with smaller crops, such as soybeans (Rezende at al., 2012), beans (Tavares at al., 2013) and corn (Silva at al., 2004), helps to reduce penetration of light in the canopy of these crops, resulting in greater production losses.

Similarly to the plant height, $S$. arundinaceum has significant root production, measured by the root volume (Figure 1B), indicating the extent of the root system of this species. Deep roots allow plants to access available 
water sources after upper soil layers dry, adapting its growth to low rainfall seasons, often becoming more competitive plants (Grieu at al., 2001).

Considering the total dry matter production of $S$. arundinaceum (Figure 2D), the plants showed slow initial growth up to 57 DAT and, thereafter, up to 113 DAT, showed fast and constant dry matter accumulation even with foliar senescence (Figure 2B) and stabilization of the stem growth (Figure 2C). This behavior is due to the accumulation of root dry matter (Figure 2A), which represented the largest fraction of dry matter accumulated by the plant.

Nevertheless, the final dry mass obtained demonstrates the high ability of this species to
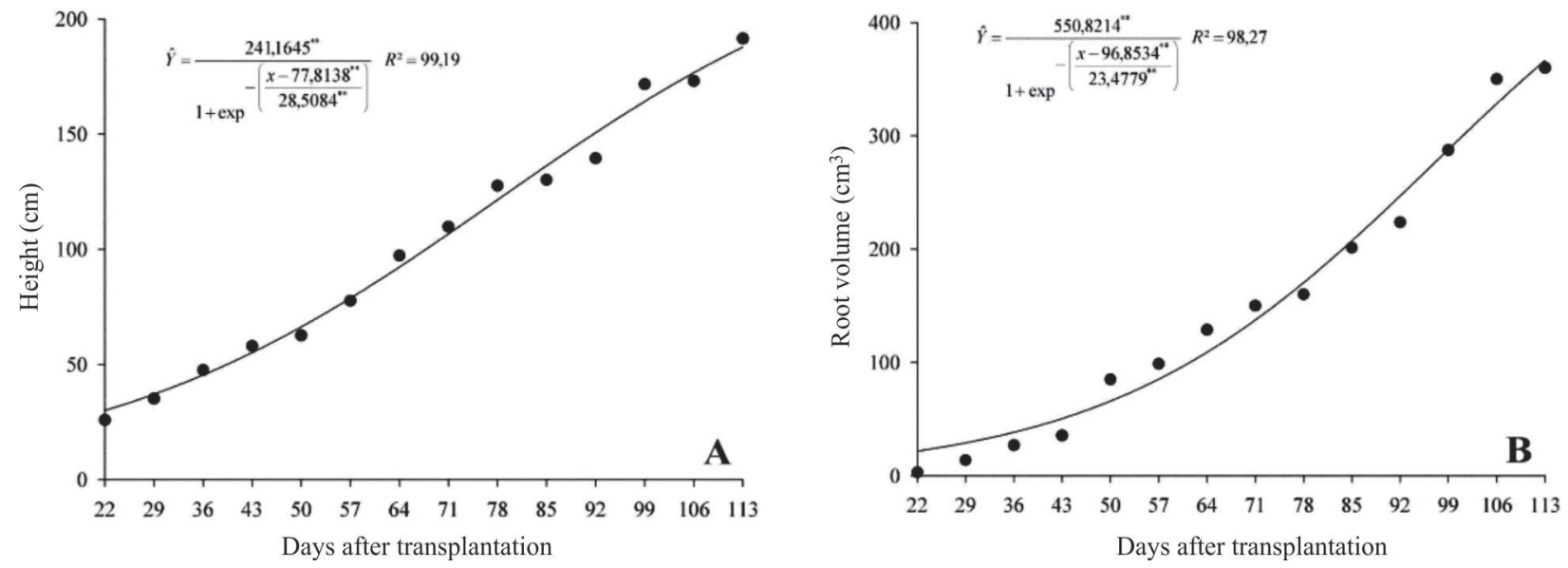

Figure 1: A- Height $(\mathrm{cm})$, B- Root volume $\left(\mathrm{cm}^{3}\right)$ of $S$. arundinaceum along its development cycle.
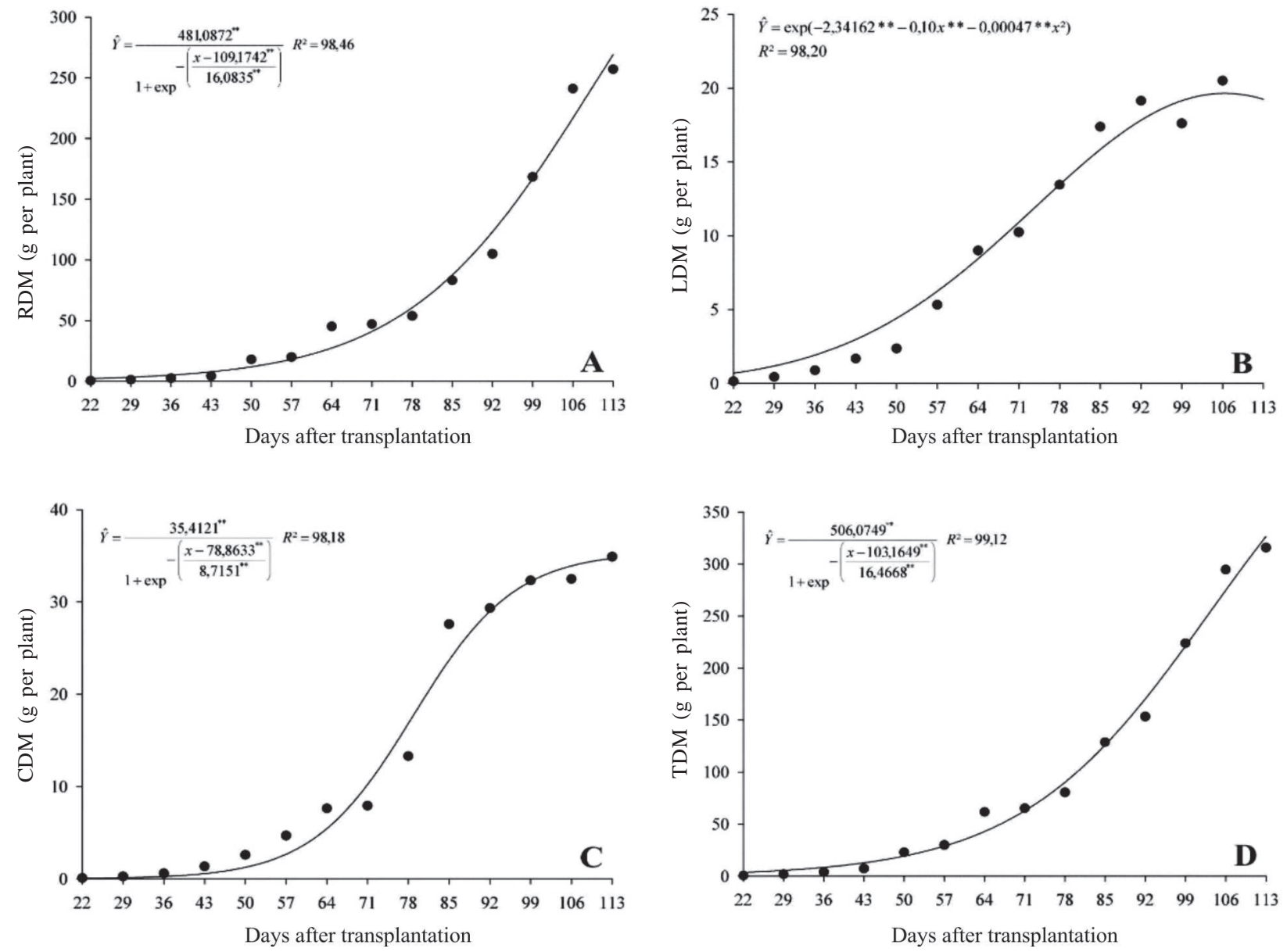

Figure 2: Dry matter accumulation of Sorghum arundinaceum along its development cycle: A - Root Dry Matter (RDM); B - Leaf Dry Matter (LDM); C - Stems Dry Matter (SDM); and D - Total Dry Matter (TDM). 
accumulate mass, especially at the end of its cycle, presenting at 113DAT, mean values of $315.77 \mathrm{~g}$ per plant, and production of approximately 257.03 and $58.74 \mathrm{~g}$ for roots and shoots, respectively. The maximum dry matter produced by $S$. arundinaceum was higher than in experiments with grass weeds Digitaria insularis (Machado at al., 2006), Chloris polydactyla (L.) Fedde (Carvalho at al., 2005b), Brachiaria decumbens Stapf (Bianco at al. 2005) and dicotyledonous weeds Siegesbeckia orientalis L. (Aguilera at al., 2004), and Richardia brasiliensis gomes (Pedrinho Jr. at al., 2004). This higher dry matter accumulation, when compared with the other species, occurred mainly by the growth habit of the plant and the $\mathrm{C}_{4}$ metabolism, that was favored by the experimental conditions of temperature and light. Silva \& Silva (2007) state that the $\mathrm{C}_{4}$ photosynthetic metabolism confer several attributes beneficial to plants, especially in hot and sunny environments, with high photosynthetic rate, low $\mathrm{CO}_{2}$ compensation point and low photorespiration rate.

For leaf dry matter, there was a more intense increase from 50 DAT, reaching the maximum accumulation after flowering, 92 DAT, showing a declining trend from 99 DAT (Figure 2B). For the stems, the stability of dry matter accumulation occurred at the end of the evaluation period, 113 DAT.

Considering the weed dry matter partitioning throughout the growth cycle, the roots present an accumulation index superior than $60 \%$ of total dry matter in relation to the other parts of the plant (Figure 3), indicating significant photoassimilate allocation in the root system. Bianco at al. (2004) found in the photosynthate partition of Rottboellia exaltata (Jacq.) Fél. that the roots at 21 DAT contributed approximately with $60 \%$ of total dry matter, but this partition was reduced with the extension of the plant cycle, reaching $40 \%$, on average, at the end of the experiment at 133 DAT. Similar behavior was observed for Digitaria insularis (MACHADO at al., 2006) and Brachiaria decumbens (BIANCO at al., 2005). This differentiated partition for $S$. arundinaceum, favoring the root system, is an important survival strategy in adverse conditions for the recruitment of resources in the soil environment.

Concerning the shoot, up to 43 DAT there was a higher average attendance of leaves in relation to the stems, from 23 to $17 \%$, respectively; however, after flowering (at 92 DAT), the leaves, main organs in the production of assimilates, reduced their participation, leading to an increased allocation to the reproductive structures and roots (Figure 3). Panicle and seed dry matters showed small average increases of 7.9 and $2.3 \%$, respectively, of the total dry matter, at 113DAT.

The leaf area of S. arundinaceum showed slow growth up to $36 \mathrm{DAT}$ and then, a rapid increase, reaching peak at 87 DAT with $876.89 \mathrm{~cm}^{2}$; from that date until the end of the test, it showed a decrease due to leaf senescence and the formation of reproductive structures (Figure 4A). It was observed for this species that, despite the size and the high dry matter accumulation, the maximum leaf area obtained was lower than in other species of $\mathrm{C}_{4}$ metabolism such as itchgrass (Carvalho at al., 2005a and b) and corn (Sangoi at al., 2007).

The higher RGRs occurred in the early growth up to 43 DAT, reaching an average value of $0.082 \mathrm{~g} \mathrm{~g}^{-1}$ day $^{-1}$ (Figure 4B). Regarding other weed species, these values were higher than those found by Machado at al. (2006) for Digitaria insularis $\left(0.072 \mathrm{~g} \mathrm{~g}^{-1} \mathrm{day}^{-1}\right)$. According to Benincasa (2003), with the increasing dry matter accumulated by plants, the need for assimilates to maintain the already formed structures increases, making the amount of photosynthate available for growth to be lower and the RGR to decrease over time.

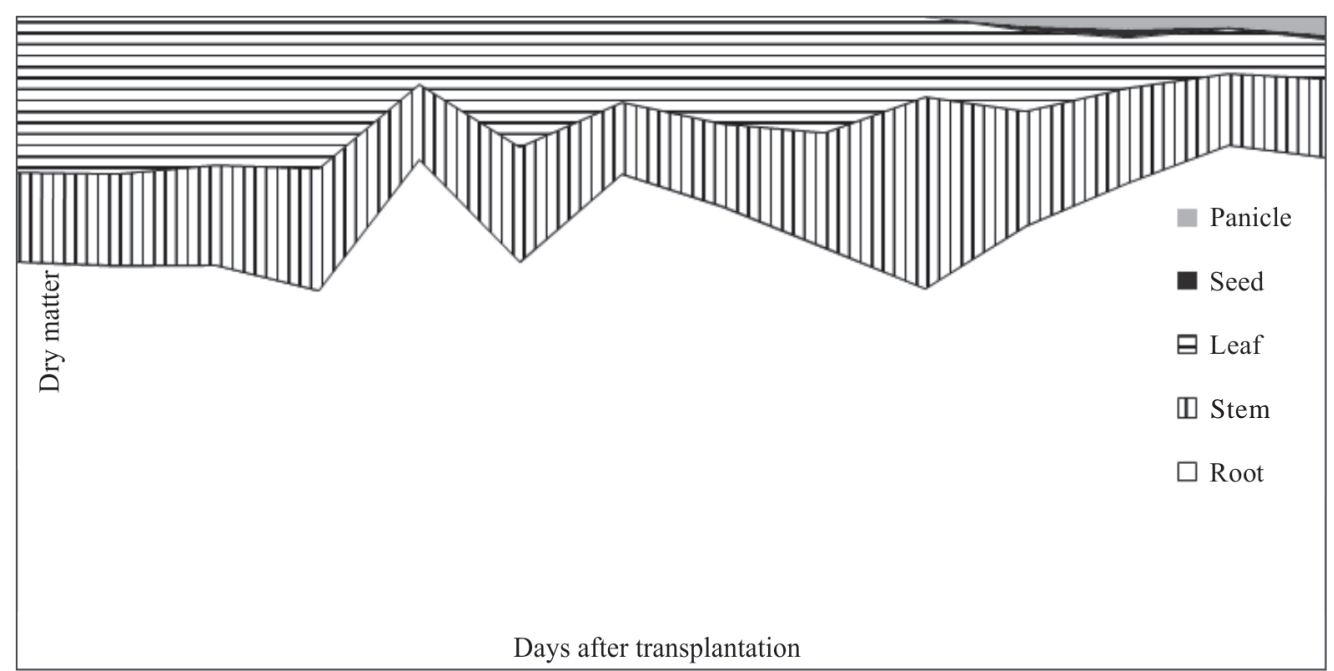

Figure 3: Percentage distribution of dry matter in different parts of Sorghum arundinaceum throughout their growth cycle. 
Specific leaf area (SLA) relates leaf area and leaf mass. S. arundinaceum showed higher values at 22 DAT, with $223.90 \mathrm{~cm}^{2} \mathrm{~g}^{-1}$, and decreasing values until the end of the experiment, with $32.21 \mathrm{~cm}^{2} \mathrm{~g}^{-1}$ (Figure 4C). Similar decreasing behavior along the $S$. arundinaceum cycle was observed for leaf weight ratio (LWR) (Figure 4D), which represents how much the plant invested of its production by photosynthesis for the leaves, showing reduction of the useful photosynthetic area and the lower participation of leaves in the total dry matter. Similar results were observed in weeds and crops (Machado at al., 2006).

In general, it was observed for this species that, despite the high height, its initial growth is slow, with high dry matter production at the end of the cycle and a high capacity to allocate assimilates in the roots.

For the results of gas exchange related to photosynthetic rate $(A)$, there was no variation in all phenological stages evaluated in the weed. However, the values were close to those found by Gonçalves at al. (2010), for sugarcane $\left(24 \mu \mathrm{mol} \mathrm{CO} \mathrm{Cm}^{-2} \mathrm{~s}^{-1}\right)$, and Carvalho at al. (2009) for corn $\left(24 \mu \mathrm{mol} \mathrm{CO}_{2} \mathrm{~m}^{-2} \mathrm{~s}^{-1}\right)$,
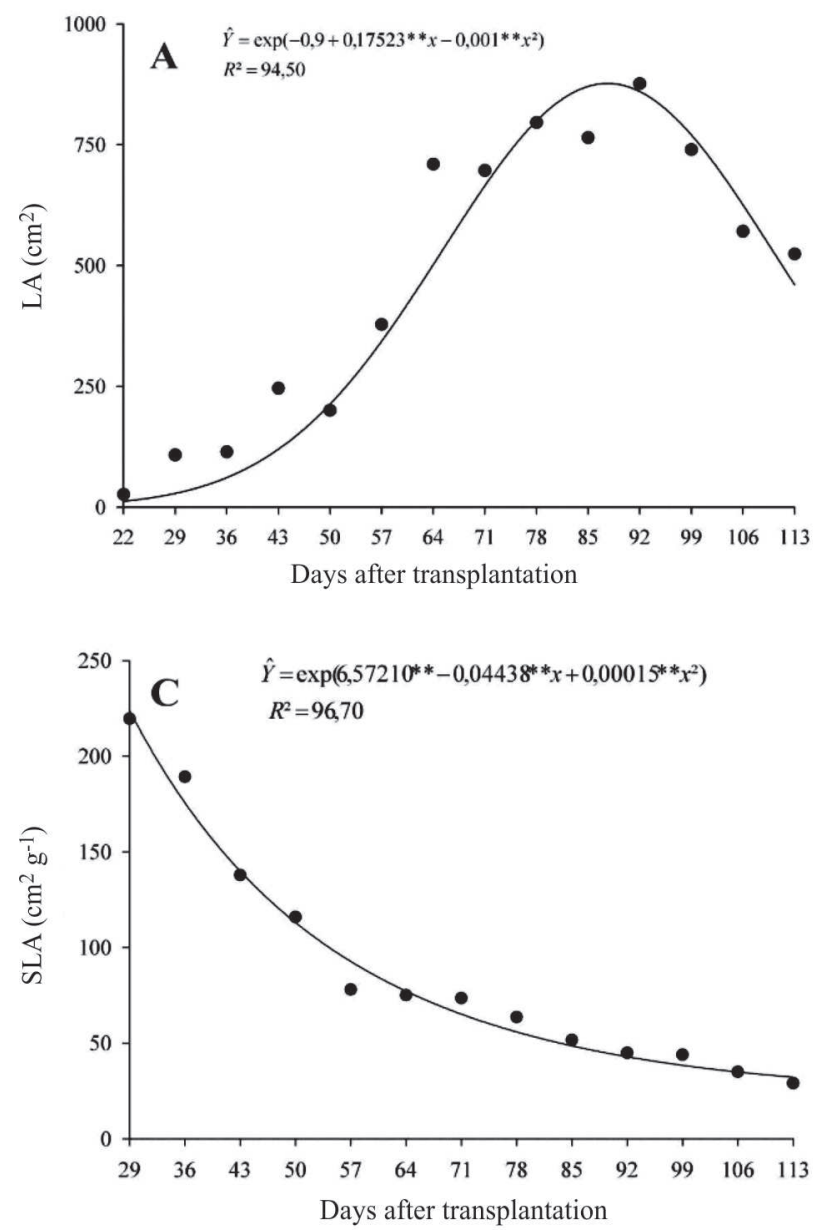

which are plants of $\mathrm{C}_{4}$ metabolism. In $\mathrm{C}_{4}$ plants, the higher net photosynthesis rates are due to the ability to concentrate $\mathrm{CO}_{2}$ at the site of rubisco, which reduces losses in the photorespiratory process that is high in $\mathrm{C}_{3}$ plants (Taiz \& Zeiger, 2013). In work by Ferreira at al. (2011), evaluating the photosynthetic activity of soybean, at the flowering period, and the weeds Brachiara decumbens and Bidens pilosa L., both of $\mathrm{C}_{4}$ metabolism during the growing season, they noted that the weeds showed similar photosynthetic activities, between 10.5 and $11 \mu \mathrm{mol} \mathrm{CO} \mathrm{m}^{-2} \mathrm{~s}^{-1}$. The activities were different from those of soybeans, which showed photosynthetic rate around $9.4 \mu \mathrm{mol} \mathrm{CO} \mathrm{C}_{2}^{-2}$ $\mathrm{s}^{-1}$. However, they all have lower values than those of $S$. arundinaceum, which showed results ranging from 20.33 to $21.87 \mu \mathrm{mol} \mathrm{CO} \mathrm{m}^{-2} \mathrm{~s}^{-1}$ (Figure 5A).

For transpiration rate $(E)$, different behaviors were found among the phenological phases of the weed $S$. arundinaceum. At the vegetative growth phase, the $E$ value was $2.69 \mathrm{mmol} \mathrm{m}^{-2} \mathrm{~s}^{-1}$, while at the flowering and maturation, it was 1.62 and $4.23 \mathrm{mmol} \mathrm{m}^{-2} \mathrm{~s}^{-1}$, respectively (Figure 5B). Gonçalves at al. (2010) observed an $E$ value
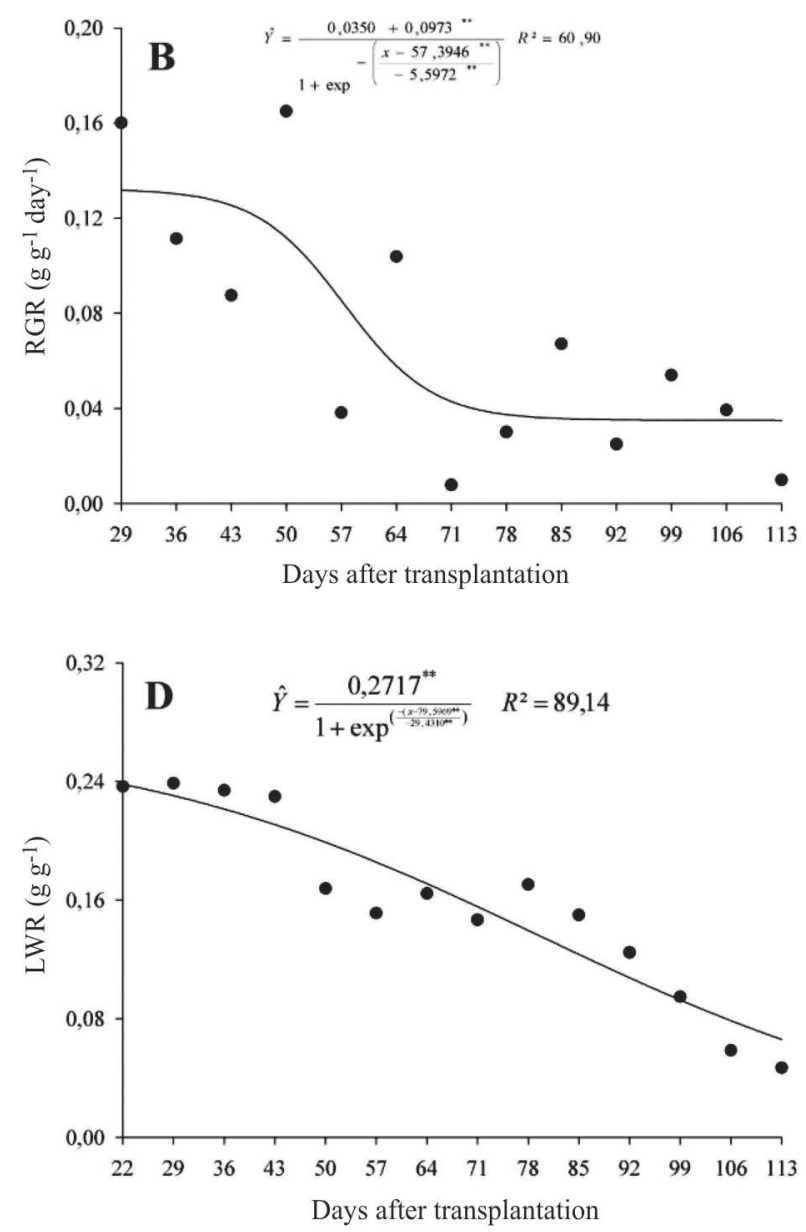

Figure 4: A- Leaf area (LA); B- Relative Growth Rate (RGR); C- Specific Leaf Area (SLA); and D- Leaf weight ratio (LWR) of Sorghum arundinaceum along its development cycle. 
of $4.5 \mathrm{mmol} \mathrm{m}^{-2} \mathrm{~s}^{-1}$ with sugarcane, similar to that observed for $S$. arundinaceum at the maturation phase, $4.23 \mathrm{mmol}$ $\mathrm{m}^{-2} \mathrm{~s}^{-1}$.

A similar behavior was observed for the stomatal conductance $(g s)$, in the different phenological phases of S. arundinaceum (Figure 5C), which also are similar to findings in the literature for sugarcane (Gonçalves at al., 2010) and corn (Magalhães at al., 2009). The conductance is proportional to the number and size of stomata and their opening diameter, which depend on factors inherent to the genotype and the environment (Brodribb \& Holbrook, 2003). In the evaluations, the ratios $\mathrm{Ci} / \mathrm{Ca}$ of $\mathrm{S}$. arundinaceum did not vary significantly over the days of evaluation (Figure 5D), oscillating between 0.333 and 0.377 .

The measurement of chlorophyll fluorescence is the technique used to investigate the photosynthetic capacity of the plant. According to Bolhàr-Nordenkampf at al. (1989), the yield of chlorophyll $a$ fluorescence reveals the level of energy excitation in the pigment system that drives photosynthesis, and provides subsidies to estimate the inhibition or damage in the electron transfer process of the photosystem II and, when the plant has its photosynthetic apparatus intact, the $\mathrm{Fv} / \mathrm{Fm}$ ratio varies between 0.75 and 0.85 .

For $S$. arundinaceum, the mean values in all phenological phases were similar and remained at 0.79 (Figure 6A), indicating that there was no photoinhibitory damage in the PS II reaction centers.

For the effective quantum yield of FS II ( $\Delta \mathrm{F} / \mathrm{Fm}$ ') and ETR there was a similar behavior, manifested by an increase of these variables in the flowering of $S$. arundinaceum, in relation to the other phenological stages (Figure 6B and 6C). According to Lu at al. (2003), the reduction of the $\Delta \mathrm{F} / \mathrm{Fm}$ ' values is reflected in the reduction of the capture efficiency of excitation energy by the FS II reaction centers, corroborating the observations of lower ETR values found at vegetative growth and at the maturation phase of $S$. arundinaceum. As for the NPQ, at maturation, values higher than those in the other phenological phases were found (Figure 6D), indicating that the plants are dissipating more energy in heat form (Figure 5B). This behavior, at the maturation phase of $S$. arundinaceum, may be associated with leaf senescence, related to leaf yellowing and the loss of chlorophyll (Falqueto at al., 2009).
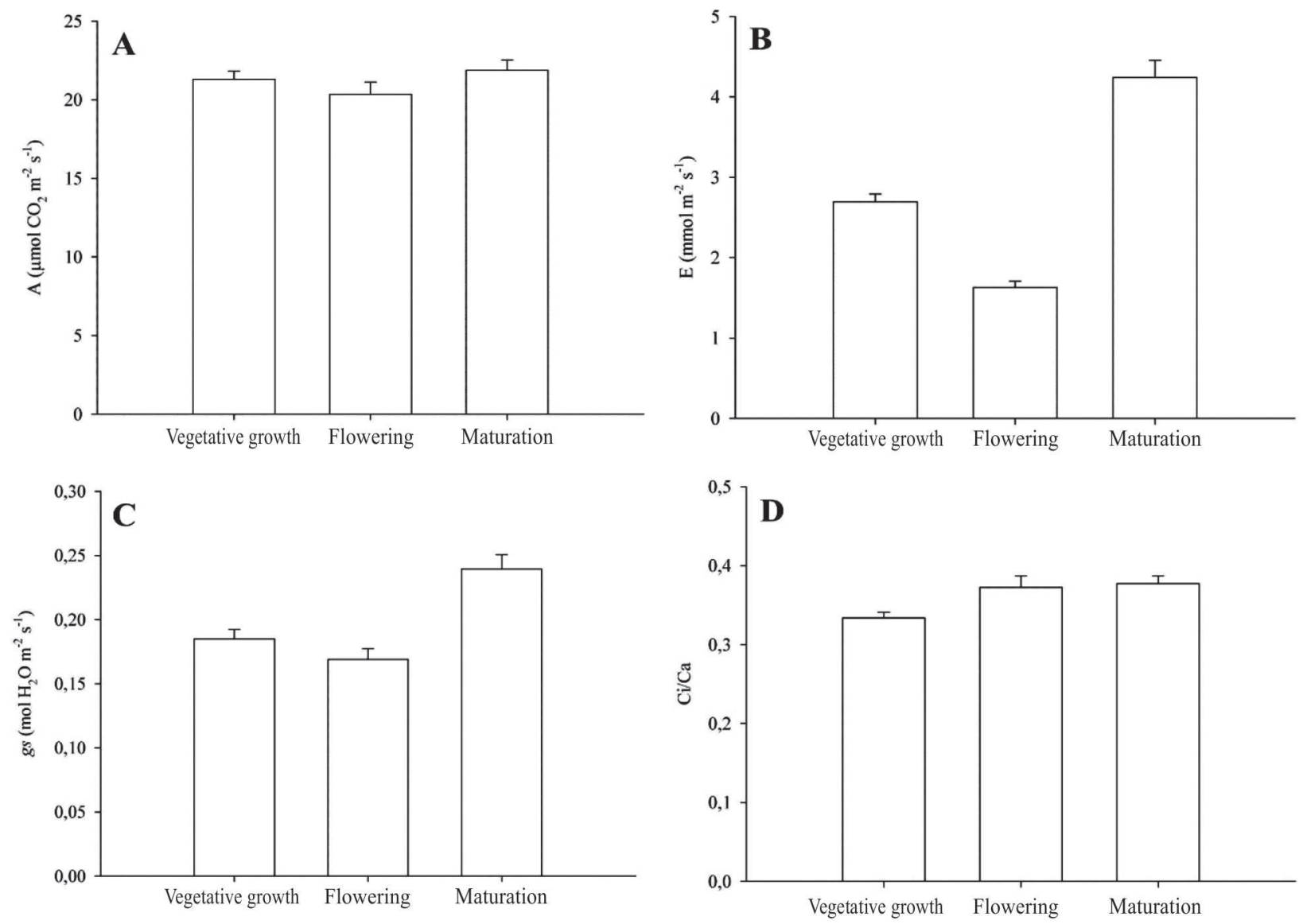

Figure 5: A- photosynthetic rate (A); B- transpiration rate (E); C- Stomatal conductance ( $g s)$; and D- ratio Ci/Ca in Sorghum arundinaceum plants at the vegetative growth, flowering and maturation.

Rev. Ceres, Viçosa, v. 63, n.1, p. 016-024, jan-fev, 2016 

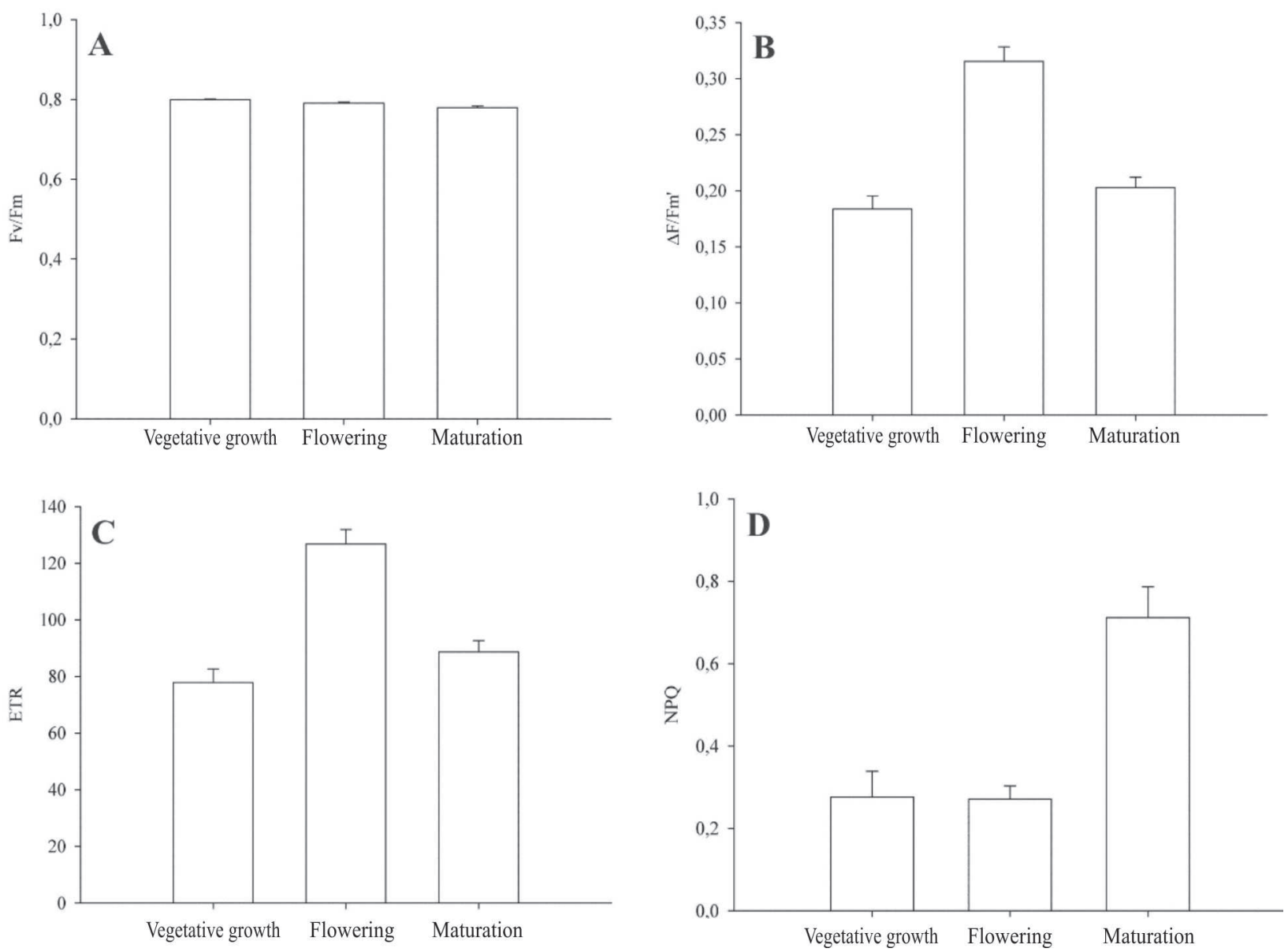

Figure 6: A- Maximum quantum yield of FS II (Fv/Fm); B- Effective quantum yield of FS II ( ̈̈F/Fm'); C- Electron transport rate (ETR); and D- Non-photochemical quenching coefficient (NPQ) in Sorghum arundinaceum plants at the vegetative growth, flowering and maturity.

\section{CONCLUSIONS}

S. arundinaceum show high size, slow initial growth, but high dry matter production at the end of cycle. Most of the dry matter is allocated in the roots. It has values of specific leaf area, relative growth rate and leaf weight ratio similar to other $\mathrm{C}_{4}$ grasses.

The photosynthetic rate and maximum quantum yield of FS II of Sorghum arundinaceum are similar throughout the plant cycle. It presents effective quantum yield of FS II and higher value of electron transport rate in the flowering period. At maturation, S. arundinaceum showed higher values of transpiration rate, stomatal conductance and non-photochemical quenching coefficient.

Considering that $S$. arundinaceum has physiological and growth characteristics similar to other invasive grasses of $\mathrm{C}_{4}$ metabolism, the management of this species requires specific care, especially in springsummer crops and in the early stages of their establishment.

\section{REFERENCES}

Aguilera DB, Ferreira FA \& Cecon PR (2004) Crescimento de Siegesbeckia orientalis sob diferentes condições de luminosidade. Planta Daninha, 22:43-51.

Aumonde TZ, Pedó T, Martinazzo EG, Moraes DM, Villela FA \& Lopes NF (2013) Análise de crescimento e partição de assimilados em plantas de maria-pretinha submetidas a níveis de sombreamento. Planta Daninha, 31:99-108.

Benincasa MMP (2003) Análise de crescimento de plantas, noções básicas. $2^{\mathrm{a}}$ ed. Jaboticabal, FUNEP. 41p.

Bianco S, Barbosa Junior AF \& Pitelli RA (2004) Crescimento e nutrição mineral de capim-camalote. Planta Daninha, 22:375380 .

Bianco S, Tonhão MAR \& Pitelli RA (2005) Crescimento e nutrição mineral de capim-braquiária. Planta Daninha, 23:423-428.

Bilger W \& Björkman O (1990) Role of xanthophyll cycle in photoprotection elucidated by measurements of light induced absorbance changes, fluorescence and photosynthesis in leaves of Hedera canariensis. Photosynthesis Research, 25:73-185.

Bolhàr-Nordenkampf HR, Long SP \& Baker NR (1989) Chlorophyll fluorescence as probe of the photosynthetic competence of leaves in the field: a review of current instrument. Functional Ecology, 3:497-514. 
Brasil (2009) Regras para análise de sementes. Brasília, Ministério da Agricultura, Pecuária e Abastecimento. 395p.

Brodribb TJ \& Holbrook NM (2003) Stomatal closure during leaf dehydration, correlation with other leaf physiological traits. Plant Physiology, 132:2166-2173.

Carvalho CM, Lacerda CF, Vieira MR, Rodrigues CF, Américo JG \& Neves ALR (2009) Comportamento ecofisiológico das culturas de milho e feijão-de-corda sob diferentes condições de cultivo. Pesquisa Aplicada e Agrotecnologia, 2:78-83.

Carvalho SJC, Moreira MS, Nicolai M, Ovejero RML, Christoffoleti PJ \& Medeiros D (2005a) Crescimento e desenvolvimento da planta daninha capim-camalote. Bragantia, 64:591-600.

Carvalho SJP, Pereira Silva RF, López-Ovejero RF, Nicolai M \& Christoffoleti PJ (2005b) Crescimento, desenvolvimento e produção de sementes da planta daninha capim-branco (Chlorispolydactyla). Planta Daninha, 23:603-609.

Castro GSA, Crusciol CAC, Negrisoli E \& Perim L (2011) Sistemas de produção de grãos e incidência de plantas daninhas. Planta Daninha, 29:1001-1010.

Falqueto AR, Cassol D, Magalhães Júnior AM, Oliveira AC \& Bacarin MA (2009) Physiological analysis of leaf senescence of two rice cultivars with different yield potential. Pesquisa Agropecuária Brasileira, 44:695-700.

Ferreira EA, Aspiazú I, Galon L, Concenço G, Silva AF \& Reis LAC (2011) Características fisiológicas da soja em relação a espécies de plantas daninhas. Revista Trópica - Ciências Agrárias e Biológicas, 5:39-47.

Genty B, Briantais JM \& Baker NR (1989) The relationship between the quantum yield of photosynthetic electron transport and quenching of chlorophyll fluorescence. Biochimica et Biophysica Acta, 990:87-92.

Gonçalves ER, Ferreira VM, Silva JV, Endres L, Barbosa TP \& Duarte $W G$ (2010) Trocas gasosas e fluorescência da clorofila $a$ em variedades de cana-de-açúcar submetidas à deficiência hídrica Revista Brasileira de Engenharia Agrícola e Ambiental, 14:378386 .

Grieu P, Lucero DW, Ardiani R \& Ehleringer JR (2001) The mean depth of soil water uptake by two temperate grassland species over time subjected to mild soil water deficit and competitive association. Plant and Soil, 230:197-209.

Hoagland DR \& Arnon DJ (1950) The water culture method of growing plants without soil. Berkeley, University of California. 31p. (Boletim técnico, 347).
Lorenzi H (2008) Plantas daninhas do Brasil: terrestres, aquáticas, parasitas e tóxicas. $4^{\mathrm{a}}$ ed. Nova Odessa, Instituto Plantarum. 384 p.

Lu C, Wang B \& Zhang J (2003) Salinity treatment shows no effects on photosystem II photochemistry, but increases the resistance of photosystem II to heat stress in halophyte Suaeda salsa. Journal of Experimental Botany, 54:851-860.

Machado AFL, Ferreira LR, Ferreira FA, Fialho CMT, Tuffi Santos LD \& Machado MS (2006) Análise de crescimento de Digitaria insularis. Planta Daninha, 24:641-647.

Magalhães PC, Souza TC, Albuquerque PEP, Karam D, Magalhães MM \& Cantão FRO (2009) Caracterização ecofisiológica de linhagens de milho submetidas a baixa disponibilidade hídrica durante o florescimento. Revista Brasileira de Milho e Sorgo, 8:223-232.

Myers CV \& Anderson RC (2003) Seasonal variation in photosynthetic rates influences success of an invasive plant, garlic mustard (Alliaria petiolata). America Midland Naturalist, 150:231-245.

Pedrinho Junior AAF, Bianco S \& Pitelli RA (2004) Acúmulo de massa seca e macronutrientes por plantas de Glycine Max e Richardia brasiliensis. Planta Daninha, 22:53-61.

Rascher U, Liebig M \& Lüttge U (2000) Evaluation of instant lightresponse curves of chlorophyll fluorescence parameters obtained with a portable chlorophyll fluorometer on site in the field. Plant Cell Environ, 23:1397-1405.

Rezende BMP, Tavares CJ, Marangoni RE, Cunha PCR \& Jakelaitis A (2012) Efeito do fomesafen + fluazifop-p-butil associados com inseticidas no controle das plantas daninhas na cultura da soja. Agrária, 7:608-613.

Sangoi L, Schmitt A \& Zanin CG (2007) Área foliar e rendimento de grãos de híbridos de milho em diferentes populações de plantas. Revista Brasileira de Milho e Sorgo, 6:263-271.

Silva LC, Beltrão EM \& Amorim Neto MS (2000) Análise de crescimento de comunidades vegetais. Campina Grande. 47p. (Boletim técnico, 34).

Silva AA \& Silva FJ (2007) Tópicos em manejo de plantas daninhas. Viçosa, Editora UFV. 367p.

Taiz L \& Zeiger E (2013) Fisiologia Vegetal. 5a ed. Porto Alegre, Artmed. 918p.

Tavares CJ, Jakelaitis A, Rezende BMP \& Cunha PCR (2013) Fitossociologia de plantas daninhas na cultura do feijão. Agrária, $8: 27-32$

Zanine AM \& Santos EM (2004) Competição entre espécies de plantas - uma revisão. Revista da FZVA, 11:10-30. 